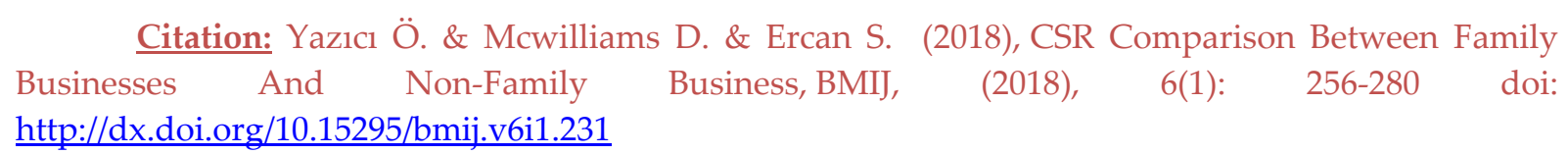

\title{
CSR COMPARISON BETWEEN FAMILY BUSINESSES AND NON- FAMILY BUSINESS
}

\author{
Ömer YAZICI ${ }^{1}$ \\ Douglas MCWILLIAMS ${ }^{2}$ \\ Seydahmet ERCAN ${ }^{3}$
}

\author{
Received Date (Başvuru Tarihi): 10/04/2018 \\ Accepted Date (Kabul Tarihi): 20/04/2018 \\ Published Date (Yayın Tarihi): 20/04/2018
}

\begin{abstract}
This paper is designed to explore whether family businesses outperform nonfamily businesses regarding Corporate Social Responsibility (CSR) performance. Upon comparing the CSR performances of 64 top family businesses in the US with CSR performances of the top nonfamily businesses in the US; the results have showed that nonfamily businesses outperform family businesses on CSR. Analysis of four out of five categories of CSR performance resulted in favor of nonfamily businesses and no statistical difference was found in one category. Hence, results show that family businesses are reluctant to corporate social responsibility concern. The result of this study may suggest that family businesses are self-interested; however, some research literature may advise otherwise. Strong agency problems and having family influence in the top management team composition may be shown as the main reason behind this phenomenon. Also results show that among the family businesses, increased family member presence in the top management has a positive effect on CSR performance. For further analysis and future studies, recommendations are made in the conclusion section.
\end{abstract}

Keywords: Family Businesses, Top Management Team Composition, Corporate Social Responsibility

JEL Codes: M10, M12, M14

\section{AİLE ŞİRKETLERİNIN AİLE ŞİRKETI OLMAYAN FİRMALAR İLE KSS HAKKINDA KARŞILAŞTIRILMASI}

\section{ÖZ}

Bu makale aile şirketlerini aile şirketi olmayan firmalarla kurumsal sosyal sorumluluk (KSS) konusunda karşılaştırmak için hazırlandı. Amerika'daki en iyi 64 aile şirketini, yine Amerika'daki en iyi 64 aile şirketi olmayan firmalar ile karşılaştırdığımızda sonuçlar gösterdi ki aile şirketi olmayan firmalar, aile şirketlerinden daha iyi KSS performansına sahip. Beş KSS kategorisinden dördünde aile şirketi olmayan firmalar istatistiksel olarak daha iyi performans gösterirken, sadece bir kategoride aralarında istatistiksel fark bulunamadı. Sonuçlar aile şirketlerinin KSS konusunda ilgisiz olduğunu ortaya koydu. Bu araştırmanın sonuçları aile şirketlerinin KSS konusunda ilgisiz olduğunu gösterse de, aksini destekleyen çalışmalar da var. Önemli derecede vekâlet problemlerinin olması ve aile bireylerinin üst kademe yönetimine ciddi derecede müdahil olması bu çelişkiye ışık tutan faktörlerdir. Ayrıca, aile şirketlerinin kendi aralarında da yapılan karşılaştırmada, üst yönetimde artan aile bireyi sayısının KSS performansını arttırdı̆̆ı görülmüştür. Araştırmanın detaylı neticesi ve ileriye dönük araştırma tavsiyeleri sonuç bölümünde sunulmuştur.

Anahtar Kelimeler: Aile Şirketleri, Üst Yönetim Oluşumu, Kurumsal Sosyal Sorumluluk

JEL Kod: M10, M12, M14

\footnotetext{
${ }^{1}$ Dr. Ömer Yazıcı, bendryazici@gmail.com

2 Asst. Prof. of Manag., Jackson State University, douglas.1.mcwilliams@jsums.edu

${ }^{3}$ Dr. Öğr.üyesi, Bülent Ecevit üniversitesi, seydahmetercan@gmail.com
}

http://orcid.org/0000-0002-6372-7755

http://orcid.org/0000-0001-5620-2312

http://orcid.org/0000-0002-9174-9249 


\section{INTRODUCTION}

Given that more than $30 \%$ of all companies with sales revenue greater than $\$ 1$ billion are family business, interest in family business studies has increased significantly, especially in the last 15 years (Kachaner, Stalk \& Bloch, 2012). In many cases, the literature (e.g., Anderson \& Reeb, 2003; Breton-Miller \& Miller, 2006; Andres, 2008; Barontini \& Caprio, 2006) points out various reasons why and how family businesses outperform nonfamily businesses. Family business characteristics have a significant effect on a company's performance through a distinct strategic decision-making process. Attributes like long-term orientation (Breton-Miller \& Miller, 2006), social responsibility orientation, non-economic goals (Lee \& Rogoff, 1996; Chrisman, Chua, \& Zahra, 2003), and other unusual characteristics create a complex structure that leads to the design a competitive resource (Miller and Le- Breton-Miller, 2005; Habbershon et al., 2003; Habbershon \& Williams, 1999) to build absorbing effect for management field researchers.

Involvement of family in business through management, governance, and ownership creates a unique and distinctive attribute of family businesses (Chrisman, Chua \& Steier, 2005). One of the unique characteristics of family businesses is the composition of the top management team. The desire to have control in the management and future of the company leads to a family business-specific upper echelon arrangement. It is empirically shown that the majority of family businesses employ family members for critical positions (Deloitte \& Touche Study, 1999). This familial human capital contains the knowledge that provides opportunities that are almost impossible to imitate.

Although there has been extensive research on family business characteristics and their effects on many strategic components, corporate social responsibility (CSR) and top management team (TMT) composition has been one of the least studied (Dyer \& Whetten, 2006). This paper aims to respond to this literature gap by exploring the relationship between family business-specific TMT composition and corporate social responsibility (CSR) of family businesses in the light of agency theory. To analyze TMT composition, we use three variables: family CEO, family chairperson, and number of family members in top management.

Researchers have reached conflicting results about relationship between CSR and financial performance of companies (McWilliams \& Siegel, 2000). Reasons behind these contradictory results are suggested to be shaky grounds (Orlitzky et al., 2003) or flawed empirical studies (McWilliams \& Siegel, 2000). Orlitzky et al. (2003) conducted a metaanalysis of 52 studies with a total sample size of 33,878 and concluded that CSR in fact pays off. 
Studies about CSR in family businesses explored different perspectives of the phenomena. Some studies found that family businesses are reluctant regarding CSR (Morck \& Yeung, 2004) and reasoned it to trust and development level of the country. On the other hand, some studies have discovered that family businesses are prone to social responsibility (Dyer \& Whetten, 2006; Godfrey, 2005) because of reasons like the family image protection and moral capital.

Upper echelon theory, proposed by Hambrick and Mason (1984), explains why focusing in single representative on TMT might cause duality in findings, and why researchers should also focus on TMTs rather than individual representatives. Upper echelon theory is one of the least applied theories in the family business literature. Kellermann and Eddleston, $(2004,2007)$ and Ling and Kellermanns (2010) are pioneers in upper echelon theory of family businesses. Ling and Kellermanns (2010) classified family business-specific TMT characteristics into three categories: generation in charge, number of family members in TMT, and number of generations employed. The authors suggest that founding generation, mainly the founder has different motivations than later generations ( Miller et al., 2007), and succeeding generations might have more homogeneous TMT compositions and purposes (Corbetta \& Salvato, 2004; Zahra and Hayton, 2004).

Upper echelons theory generally focusses on entire top management team as an important level of analysis, but there are arguments supporting contrary view. Cannella and Holcomb (2005) argue that strong leader like CEO or chairman could diminish the power of group characteristics. Minichilli, Corbetta and MacMillan (2010) suggest that this is more prominent in the case of family businesses where $\mathrm{CEO}$ or chairman has more power to influence corporate decisions and outcomes. Furthermore, Minichilli, Corbetta and MacMillan (2010) studied the family member and family CEO presence in the top management and concluded that even though family CEO should benefit the company, coexistence of 'factions' among the top managers will eventually hurt the business. Hence, in this study, family CEO, family chairman and total number of family members in TMT are used to analyze importance of TMT composition.

Definition of family businesses has not gotten to a particular stage. Some authors have defined family business differently (Sharma et al., 1997; Litz, 1995). Some major components used by authors to define family businesses: family management (active family members in business operations), family ownership (family holds majority of ownership), and multiple generational ownership (Chua et al., 1999). In this study, we use the definition of Chua, Chrisman, and Sharma (1999): “A family business is defined as a company governed and/or 
managed by a family or a small group of families to pursue the vision of the business and to be sustainable across generations." Hence, we can assume that nonfamily businesses are companies that are governed or managed by nonrelated individuals, or groups that have vision to have profitable investment for themselves and their stakeholders. Therefore, according to this definition, single owner businesses are not family businesses, while companies like Walmart is not a nonfamily business although they are traded publically in the stock market.

Main research question of the study is as follows: 1) How does family businesses differ from nonfamily businesses regarding to CSR performance? and 2) Is there any effect of TMT composition of family businesses? Hence, analyzing family businesses in The United States regarding top management characteristics and CSR ratings serves two main research streams in family business literature. First, it brings to light how family businesses differ in CSR performance compared to nonfamily businesses. Second, it explores the relationship between prominent TMT characteristics of family businesses and their effects on CSR behavior of the business. The remainder of this paper is as follows. In section two, a detailed literature review and hypotheses are provided. The methodology is covered in section three. Section four gives analysis about results. In section five, the discussion of results, and finally section six, the limitations and future research suggestions are presented.

\section{THEORY AND HYPOTHESIS}

\subsection{Agency Theory}

Agency theory is mainly used when there are problems between owners (principals) and managers (agents). According to this theory, managers' interests are not always in lined with the owners. Hence, Jensen and Meckling (1976) coin the phrase "agency costs" referring to this problem. Agency theory is one of the main theories that allows researchers to study the differences between family and nonfamily businesses.

According to researchers, family businesses are prone to few agency problems like family control (Thaler \& Shefrin, 1981), asymmetric altruism (Schulze et al., 2001), and nepotism (Ewing, 1965). According to Morck and Yeung (2003), family control could bring bigger, maybe worse corporate governance problems when compared to an average nonfamily business. Furthermore, researchers argue that inherited wealth could result in low economic growth due to reluctance of each succeeding generation and possibly heirs being less hardworking and ethical.

Presence of nepotism is an existential fact of family businesses. To be a family business, there has to be multiple family members attached to the company (Chua et al., 1999). Problems start rising when founding family member(s) start taking irrational decisions towards family 
members. For instance, it is not always possible to replace ineffective family members, and this might result in lower economic performance and lower performing human resource and in some cases to discriminate towards family members (Schulze et al., 2001). Keeping family members in position could also result in dysfunction of self-control mechanism by keeping whistleblowers out of corporation.

Having family members in the top management is like a double edge sword for family and outsiders. Increased number of family members in top management could do more hazard than good, and existence of family CEO and chairman could lead businesses not always towards greater good of outsiders, but towards the needs of family.

\subsubsection{CSR performance and Family Business}

Corporate Social Responsibility performance is an important factor for businesses to show that they care about the people, environment, and government that they are surrounded with. Researchers used those CSR ratings to understand and evaluate the CSR activities of businesses (Thanetsunthorn and Wuthisatian, 2016; Bouvain, et al., 2013; Manner, 2010). CSRhub.com is one of the channels that provide CSR rating and rankings for more than 17,000 companies. Similar to Kotler and Lee's (2005) six major categories of CSR initiatives, CSRhub.com has four main categories of ratings along with the overall rating. Community rating evaluates the performance in human rights, supply chain, product quality \& safety, product sustainability, community development, philanthropy topics. Employee rating evaluates the performance in diversity, labor rights, treatment of unions, compensation, benefits, training, health, worker safety topics. Environment rating evaluates the performance in Environmental policy, environmental reporting, waste management, resource management, energy use, climate change policies and performance topics. Last governance rating evaluates the performance in Leadership ethics, board composition, executive compensation, transparency and reporting, stakeholder treatment topics.

O'Boyle, Rutherford, and Pollack (2010) showed both edge of the phenomenon. These authors argue that while ownership, control and professionalism are negatively and significantly associated with ethical focus, value congruence factor (importance of shared values among group members) and participative continuance factor (intention for generational succession among family members) are both positively and significantly related to ethical focus. Perspectives that are supporting that family businesses are more socially responsible compared to nonfamily businesses are product of two main conclusions; (1) family businesses are responsible to keep their family name clean (Dyer \& Whetten, 2006) and (2) concentrated management composition and reduced agent principal conflict are more effective and 
responsible (Chu, 2011). Chu (2011) suggests that there is a strong positive relationship between business performance and family involvement. This relationship is much apprehensible when family members serve as CEO, chairman or top managers and directors of the businesses. On the contrary, this relationship is weak when family members are not involved in business management or control.

Morck and Yeung (2004) showed that family businesses are not significantly paying attention to social responsibilities and being more self-interested than nonfamily businesses. Supporting that view, Anderson \& Reeb (2003) argued that concentrated shareholders are essentially less efficient and ethical. On the contrary, Godfrey (2005) suggested that it would be more important for all businesses, including family businesses to be more socially responsible to have positive reputation in the eyes of society, which will benefit in the time of crisis. Dyer and Whetten (2006) took that argument and put it further limitations suggesting that family businesses pay more attention to social responsibility compared to nonfamily businesses, and this might be due to family orientation and to protect family reputation and image.

Ensley et al., (2007) suggested that nonfamily businesses have better self-correction mechanisms for organizational justice issues (like pay dispersion) than family businesses. Based on studies of Schulze et al. (2001), asymmetric altruism and self-control could result in shirking and free riding in two ways. First, these two mechanisms limit the enforcements between owners and managers, and second, they impact the performance evaluations. There are multiple studies showing the down sides of altruism on family businesses (e.g., Chrisman, et al., 2007; Karra et al., 2006; Schulze et al., 2001). Considering the agency theory and notorious character of family businesses, and based on the fact that they have internal issues like nepotism and asymmetric altruism, we argue that family businesses would have lower CSR performance than nonfamily businesses. According to Morck and Yeung (2003), family control could bring bigger, maybe worse corporate governance problems when compared to an average nonfamily business. Power poisoning of family managers, selfishness of owners or owning family managers, extensive nepotism, and corporate blindness due to seeing and hearing same people with same ideas creates doubtful management and unexpected results. Hence, we hypothesize our first claim as below;

Hypothesis 1: Nonfamily businesses have better CSR performance than family businesses. 


\subsection{Upper Echelons Theory}

Today's businesses competing in highly competitive markets decisions are not always the product of a single representative, but it is true that CEO or chairman of the board is the visible face of the company and driving forces for decisions. Drucker (1974) argue as well as that CEO's and chairman, in big organizations whole team is to be responsible with all management responsibilities, implying that CEOs or presidents are not the only sources to understand the complex decisions made in the company. Some scholars (e.g. Gupta, 1998) suggest that TMT analysis reveals better results than studies focused only on CEOs. Hambrick and Mason (1984) explain that phenomenon in the upper echelon theory and suggest examining the relationship between TMTs and organizational outcomes.

Top management literature differs in terms of construction of TMT. There are practical and conceptual differences as well (Carpenter et al., 2004). Initial upper echelon studies defined TMT as executives who served on board of directors (i.e. Finkelstein \& Hambrick, 1990; Haleblian \& Finkelstein, 1993) while later studies have broader perspective with including senior executives and board members (Carpenter \& Fredrickson, 2001; Murray, 1989). In this study, we apply the broader definition of TMT which is including members of board of directors and the executive team.

\subsubsection{Top Management Team Composition and CSR Performance}

Several studies exist about how top management compositions effect financial outcomes, but there are not much studies focusing on CSR and TMT relationships. Furthermore, Carpenter et al. (2004) suggest that existing studies about upper echelon theory have significantly strengthened the theory and now researchers should focus on using this approach in some other critical research areas like CSR and ethics (Manner, 2010). Waldman and Siegel (2008) suggest that although top managers are key for CSR, very few empirical studies have done on this topic. In addition, top management studies related to CSR are limited in the family business concepts. Further, Chrisman et al. (2003) suggest that unanswered questions regarding differences in family and nonfamily businesses are best addressed by applying mainstream theories of the business. Following this direction, this study is shaped around TMT composition and CSR in family businesses.

Diversity is described as double-edged sword by researchers because it has both positive and negative effects on business performance (i.e. Finkelstein \& Hambrick, 1996). On one hand, diversity provides the wide range of cognitive resources, which enable businesses to acquire more knowledge, creativity, and performance (Haleblian \& Finkelstein, 1993; Hambrick et al., 1996). On the other hand, possible control and coordination problems diminish 
the performance (Simons et al., 1999; Smith et al., 1994). Briefly, by mitigating the possible negative effects of diversity, businesses may increase the benefits that bear with diversity (Ling \& Kellermanns, 2010).

O’Boyle, Rutherford and Pollack (2010) suggest that having a high percentage of participating family members, across multiple generations, who share values and who desire to keep the business in the family is the key for ethically focused businesses. Wiersema et al. (1992) suggest that because of shared cohort membership, people would be exposed to similar social, environmental, and organizational events. Therefore, it is expected to develop a shared language due to similar experiences, backgrounds, beliefs, and values (Allen \& Cohen, 1969; Rhodes, 1983), which will increase the communication frequency and integration (O'Reilly, Caldwell, \& Barnett, 1989; Wagner, Pfeffer, \& O'Reilly, 1984; Zenger \& Lawrence, 1989). Too, Byrne and Wong, (1962) emphasize that group identification and cohesion rise with increased similarity of group members, specifically with increased values, beliefs, and attitudes, which may result in corporate blindness where people have extensively similar views which may limit their understanding of other stakeholder's expectations; therefore, limiting the absorbing contrary views and responding to outsider's requests.

O'Boyle, Rutherford and Pollack (2010) suggest that having a high percentage of participating family members, across multiple generations who share values and have desire to keep the business in the family is the key for ethically focused businesses. On the other hand, Minichilli, Corbetta and MacMillan (2010) explore a U-shaped relationship between the ratio of family members in the TMT and business performance and suggest that although the presence of a family CEO is beneficial for business performance, the coexistence of 'factions' in family and nonfamily managers within the TMT has the potential to create schisms among the subgroups and consequently hurt business performance. Younger generations are more enthusiastic about entrepreneurial activities and easy on the risky decisions (Kellermanns \& Eddleston, 2006). It is expected to see some risk and entrepreneurial activities (Ling \& Kellermanns, 2010) and ignore CSR in the business decisions.

Anderson and Reeb, (2003) proposed that since families have historical presence, united equity share and role in the management team, they have power to influence and monitor the business. Combined ownerships can be a control mechanism to mitigate managerial expropriation (Demsetz \& Lehn, 1985). This contradicts the view that concentrated shareholders are essentially less efficient and ethical (Anderson \& Reeb, 2003). Hence, we hypothesize our last claim as below; 


\section{Hypothesis 2: Increased number of family members in TMT composition will decrease the CSR performance of family businesses.}

\subsubsection{Family CEO and Chairman}

It is assumed that family managers have same interests with all other family managers/owners; but there are researchers supporting contrary view. Those researchers suggest that some managers might have risk averse behavior, reluctance to innovate and focused on short term profits ( Davis \& Harveston, 1999). Gomez Mejia et al., (2001) suggest that family members might want to pursue personal agenda rather than common purpose of the company and its owners. Following that view, Minichilli et al. (2010) suggest that potentially family members in TMT could increase the agency threat and manipulate CEO's altruism toward their personal agenda rather than reducing the agency cost. Assumption that family members should act according to the best benefits of the company could be oversighted considering possible familial bonds to create incentives to act opportunistically, in another words, create moral hazard. Examples of moral hazard are free riding and shirking.

Studies about the low performance of family businesses showed that hiring familial CEO rather than professional nonfamily one could be the result of wasteful nepotism (Bertrand \& Schoar, 2006) and a failure of meritocracy (Caselli \& Gennaioli, 2013). Hence, this inherited control could result in low performance of the family businesses, including the low performance of CSR activities.

Board of directors in the family businesses serve as a monitoring mechanism to protect the shared interests of the owner family members. Therefore, family member chairman would serve as the knight of the family in the company to guide and shape the organization according to needs of the owning family. This might result in unfavorable outcomes for nonfamily stakeholders of the company. Concentrated ownership would influence the CEO or the board of directors, specifically the chairman, to be either more risk taking or risk averse in the decisions that are not always approved by the family.

Family has significant power when CEO or the chairman is from the family members. Therefore, it is possible that when a decision is in favor of the other stakeholders rather than family members, that decision could be easily overridden by family CEO or the chairman. Hence we hypothesize as below;

Hypothesis 3: Presence of Family CEO diminishes the CSR performance of family businesses in all categories. 
Hypothesis 4: Presence of Family Chairman diminishes the CSR performance of family businesses in all categories.

\section{METHODOLOGY}

\subsection{Sample Data}

This study relies on secondary data that are collected from multiple sources. CSR ratings for five categories are collected from CSRhub.com. All other demographics data like age, size, TMT composition etc. are collected from various sources including official corporate websites and databases like Mergent Online which includes D\&B Private Company Database. Family business names are taken from Family Business 100 list of America's largest family companies published by Family Magazine in 2011. Each of the family businesses is analyzed for its TMT compositions. We investigate the specific characteristics of TMT, regarding number of family members, and family CEO or chairman of the board. In addition to top management characteristics, companies are analyzed according to their size (number of employees), and age of the company. Nonfamily business names are taken from Fortune 500 list; therefore, top family businesses are compared with top businesses in the US. Due to data limitations and existence of family businesses in Fortune 100 list, number of nonfamily businesses are also reduced to 64 .

Researchers (e.g. Thanetsunthorn and Wuthisatian, 2016; Bouvain, et al., 2013) use data from CSRhub.com to analyze the corporate social responsibility performance of the companies. CSRHub is a privately owned entity, which rates CSR and sustainability for more than eight thousand companies around the world. For the rating CSRHub combines data from nine leading research businesses: Asset4/Thomson Reuters, Carbon Disclosure Project (CDP), EIRIS, GovernanceMetrics International/Corporate Library, IW Financial, MSCI (ESG Intangible Value Assessment and ESG Impact Monitor), RepRisk, Trucost and Vigeo. This rating is a product of a lengthy filtering and complex research. This process is consisting of 6 steps: creating a central schema of the data, converting the data to a numeric scale, normalizing the scores, aggregate based on its value, trim ratings that has missing information, and evaluate all scores based on their industry. Hence, ratings are robust and valuable. Rating scale is ranging from 0 to 100 for each company, zero being lowest and one hundred being the highest. Users of CSRhub.com software can prioritize certain elements of CSR which will affect the score, but for the purpose of this study, we kept all conditions the same.

From the list of top 100 family businesses, number of companies available to analyze reduced to 64 due to data limitations in CSRhub, and limitations of collecting data for privately 
held companies. CSR ratings for each company are divided into five categories including an overall score. Community score, employees score, environment score and governance score are four main categories. We created a profile that weights those categories equally to eliminate the bias. In another words, each category is weighted the same and had same level of importance.

\subsection{Variables}

\subsubsection{Dependent Variables}

\section{CSR Ratings}

Company overall rating as well as community, environment, employee and governance ratings are dependent variables in this study. Effects of TMT composition and some other demographic variables are analyzed on the change of CSR ratings for those individual family businesses. The results provide a benchmark to conclude whether family influence on management has positive or negative effect on CSR ratings. Furthermore, family business CSR performance is compared with nonfamily businesses to analyze if family businesses superior than nonfamily businesses.

Characteristic of the CSRhub ranking scale is different than those scales developed by researchers to investigate a phenomenon. Researchers use multiple items to create a measure for a phenomenon, and mostly employ Likert scale. To assess the reliability of a primary survey data, Cronbach Alpha score is widely used method. Nevertheless, CSRhub rankings are not developed in such manner. Patent pending method of creating unique CSR ratings for each company is not applicable for Cronbach Alpha use. Therefore, we didn't employ reliability tests for our dataset.

\subsubsection{Independent Variable}

\section{TMT Composition}

Various factors effect CSR ratings of a company; but in this study, we analyze effects of TMT composition of a family business. Therefore, our independent variables are number of family members in top management, family CEO and family Chairman. Because we only focus on top 100 family businesses, it is very unlikely to obtain enough primary data for specific topic. Therefore, our study relies on secondary public data collected from reliable sources. Family business specific data had been collected from multiple sources including CSRhub.com, official corporate websites and databases like Mergent Online which includes D\&B Private Company Database. Number of family members in top management is measured with scale data. It ranges from 1 to 7. 


\section{CEO and Chairman of Company}

The effects of existence of Family CEO or chairman are analyzed. Many studies investigate the effects of CEO on CSR of nonfamily businesses (Mc Guire et al. 2003; Ramasamy et al. 2007) as well as family businesses (Godos-Díez et al., 2011; Block \& Wagner, 2010), therefore making some interpretations about CEO effect contributes the findings in this field. Further, because most families control the business through board of directors, investigating the effects of family chairman on CSR ratings add great contribution to literature. This variable is coded (1) for existence of a CEO or chairman, and ( 0 ) for non-existence, making it a categorical variable.

\section{Control Variables}

Size of the company and age of the company are used as control variables. The size of the company has been proven (Deniz \& Suarez, 2005; Jenkins, 2006; Besser \& Miller, 2001; Besser, 1999) significant to CSR policies of companies. The size of the company is measured with ratio data. Company sector is also another important factor effecting the decisions of the company. In addition to size, age of the company is also important factor for corporate decisions. Company age is also ratio data. Company sector is considered to be important as a control variable but due to having about eight different sectors and having few number of companies in some sectors, this variable is not included in the analysis.

\section{ANALYSIS}

Descriptive statistics, including means, standard deviations, and correlations among variables are presented in Table 1. Correlations in Table 1 provide insights about relationship of variables. Negative correlation between variables indicate negative relationships among variables. This is in the supporting direction for our hypotheses. Furthermore, control variable of company size had no relationship with all other variables, this was an unexpected result. 
Table 1. Descriptive Statistics

\begin{tabular}{|c|c|c|c|c|c|c|c|c|c|c|c|c|c|c|}
\hline \multicolumn{2}{|r|}{$\begin{array}{c}\text { Table 1: Descriptive } \\
\text { Statistics }\end{array}$} & Mean & St. Deviation & 1 & 2 & 3 & 4 & 5 & 6 & 7 & 8 & 9 & 10 & 11 \\
\hline 1 & Type of Comp. & 0.50 & 0.50 & 1 & & & & & & & & & & \\
\hline 2 & Family CEO & 0.22 & 0.42 & $.529^{* *}$ & 1 & & & & & & & & & \\
\hline 3 & Family Chairman & 0.38 & 0.49 & $.775^{* *}$ & $.605^{* *}$ & 1 & & & & & & & & \\
\hline 4 & \# of Family Members & 1.27 & 1.68 & $.758^{* *}$ & $.448^{* *}$ & $.689^{* *}$ & 1 & & & & & & & \\
\hline 5 & size \# employe & 105059.03 & 209822.83 & -0.136 & $-.196^{*}$ & -0.065 & -0.122 & 1 & & & & & & \\
\hline 6 & Age of company & 83.62 & 42.82 & -0.049 & -0.017 & -0.040 & -0.015 & -0.044 & 1 & & & & & \\
\hline 7 & Overall Rating & 55.27 & 7.53 & $-.372^{* *}$ & $-.231^{* *}$ & $-.364^{* *}$ & $-.209^{*}$ & 0.006 & $.275^{* *}$ & 1 & & & & \\
\hline 8 & Comm. Ratings & 52.98 & 7.96 & $-.197^{*}$ & -0.120 & $-.247^{* *}$ & -0.098 & -0.083 & $.198^{*}$ & $.868^{* *}$ & 1 & & & \\
\hline 9 & Empl. Ratings & 57.86 & 10.77 & $-.540^{* *}$ & $-.359^{* *}$ & $-.432^{* *}$ & $-.276^{* \star}$ & 0.032 & $.217^{*}$ & $.827^{* *}$ & $643^{* *}$ & 1 & & \\
\hline 10 & Envir. Ratings & 56.59 & 9.55 & $-.326^{* *}$ & $-.188^{*}$ & $-.280^{* *}$ & $-.229^{* *}$ & 0.096 & $.220^{*}$ & $.840^{* *}$ & $.715^{* *}$ & $.577^{* *}$ & 1 & \\
\hline 11 & Govern. Ratings & 54.23 & 7.97 & -0.097 & -0.063 & $-.211^{*}$ & \begin{tabular}{|l}
-0.072 \\
\end{tabular} & \begin{tabular}{|l|}
-0.035 \\
\end{tabular} & $271^{* *}$ & $.735^{* *}$ & $539^{* *}$ & $422^{* *}$ & $497^{* *}$ & 1 \\
\hline
\end{tabular}

To test our hypotheses about TMT composition and CSR relationship, we employed regression test to see if there is a significant relationship. In the relationship test, we had alpha level less than 0.01 for strong significance, 0.01-0.05 as a medium significance, and 0.05-0.10 as a weak significance.

\begin{tabular}{lccc}
\hline TABLE 2 & \multicolumn{3}{c}{ Predictor Variable: Type of Company } \\
\hline \multirow{3}{*}{ Coefficients for } & R Square & Unstandardized \\
\hline Overall Rating & 0.14 & -5.58 & Beta \\
Community Rating & 0.04 & -3.13 & 0.00 \\
Employee Ratings & 0.29 & -11.59 & 0.03 \\
Governance Ratings & 0.00 & -1.55 & 0.27 \\
Environment Ratings & 0.11 & -6.20 & 0.00 \\
\hline
\end{tabular}

Table 2 shows the result of regression analysis testing Hypothesis 1 stating that nonfamily businesses have better CSR performance in all five categories compared to family businesses. Because family businesses were coded " 1 " and nonfamily businesses " 0 ", results indicate that 4 out of 5 CSR performance categories resulted in favor of nonfamily businesses. All unstandardized $B$ values are negative and this indicates family businesses have lower CSR performance than nonfamily businesses. 
Ömer YAZICI \& Douglas MCWILLIAMS \& Seydahmet ERCAN

\begin{tabular}{|c|c|c|c|c|c|c|c|c|c|c|}
\hline \multirow{3}{*}{$\begin{array}{l}\text { TABLE } 3 \\
\text { Pred. Control Variables }\end{array}$} & \multicolumn{10}{|c|}{ Coefficients for Dependent Variables } \\
\hline & \multicolumn{2}{|c|}{ Overall Rating } & \multicolumn{2}{|c|}{ Community Rating } & \multicolumn{2}{|c|}{ Employee Ratings } & \multicolumn{2}{|c|}{ Governance Ratings } & \multicolumn{2}{|c|}{ Environment Ratings } \\
\hline & UnStd. Beta & 0.00 & UnStd. Beta & 0.00 & UnStd. Beta & 0.00 & UnStd. Beta & 0.00 & UnStd. Beta & 0.00 \\
\hline \multirow[t]{3}{*}{ Company Size } & R Square & 0.00 & R Square & 0.01 & R Square & 0.00 & R Square & 0.00 & R Square & 0.01 \\
\hline & Sig.* & 0.95 & Sig.* & 0.35 & Sig.* & 0.72 & Sig.* & 0.70 & Sig.* & 0.28 \\
\hline & UnStd. Beta & 0.05 & UnStd. Beta & 0.04 & UnStd. Beta & 0.05 & UnStd. Beta & 0.05 & UnStd. Beta & 0.05 \\
\hline \multirow[t]{2}{*}{ Company Age } & R Square & 0.08 & R Square & 0.04 & R Square & 0.05 & R Square & 0.07 & R Square & 0.05 \\
\hline & Sig.* & 0.00 & Sig.* & 0.03 & Sig.* & 0.01 & Sig. ${ }^{*}$ & 0.00 & Sig. ${ }^{*}$ & 0.01 \\
\hline
\end{tabular}

$* P<0.05$

Table 3 shows the impact of control variables, company size and age. Company size did not have any significant results for any of the CSR ratings, but company age has significant ratings for all. Results indicating that increased age of the company, increases the CSR performance. Because size of the company did not have any significant results, we did not include it in further analysis.

\begin{tabular}{|c|c|c|c|}
\hline \multirow[b]{3}{*}{ Coefficients for } & \multicolumn{3}{|c|}{ Predictor Variable: Type of Company** } \\
\hline & \multicolumn{3}{|c|}{ Unstandardized } \\
\hline & R Square & Beta & Sig.* \\
\hline Overall Rating & 0.20 & -5.39 & 0.00 \\
\hline Community Rating & 0.07 & -2.98 & 0.03 \\
\hline Employee Ratings & 0.33 & -11.39 & 0.00 \\
\hline Governance Ratings & 0.08 & -1.34 & 0.33 \\
\hline Environment Ratings & 0.15 & -6.01 & 0.00 \\
\hline
\end{tabular}

\begin{tabular}{lccc}
\hline TABLE 2 & \multicolumn{3}{c}{ Predictor Variable: Type of Company } \\
\hline Coefficients for & R Square & Unstandardized \\
\hline Overall Rating & 0.14 & -5.58 & Sig. $^{*}$ \\
Community Rating & 0.04 & -3.13 & 0.00 \\
Employee Ratings & 0.29 & -11.59 & 0.00 \\
Governance Ratings & 0.00 & -1.55 & 0.27 \\
Environment Ratings & 0.11 & -6.20 & 0.00 \\
\hline * $p<0.05$ & & &
\end{tabular}

Table 4 shows the results after controlling for company age, and still results are the same, nonfamily businesses outperform family businesses in 4 out of 5 categories. All of the $p$ values are less than 0.05 and beta values are negative. Therefore, Hypothesis 1 is partially supported.

\begin{tabular}{lccc}
\hline \multicolumn{1}{c}{ TABLE 9 } & \multicolumn{3}{c}{ Predictor Variable: \# of Family Members } \\
\hline & & Unstandardized \\
Coefficients for & R Square & Beta & Sig. $^{*}$ \\
\hline Overall Rating & 0.044 & -0.939 & 0.018 \\
Community Rating & 0.010 & -0.466 & 0.270 \\
Employee Ratings & 0.076 & -1.771 & 0.002 \\
Governance Ratings & 0.053 & -1.305 & 0.009 \\
Environment Ratings & 0.005 & -0.344 & 0.418 \\
\hline
\end{tabular}

$* p<0.05$ 
Hypothesis 2 stating that increased number of family members in TMT composition will decrease the CSR performance of family businesses is tested with regression analysis and results are shown in Table 9. According to results shown in Table 9, increased family presence in TMT results negative impact in 3 out of 5 categories of CSR performance.

\begin{tabular}{|c|c|c|c|c|c|c|c|}
\hline TABLE 9 & \multicolumn{3}{|c|}{ Predictor Variable: \# of Family Members } & TABLE 10 & \multicolumn{3}{|c|}{ Predictor Variable:\# of Family Members } \\
\hline & \multicolumn{3}{|c|}{ Unstandardized } & & \multicolumn{3}{|c|}{ Unstandardized } \\
\hline Coefficients for & RSquare & Beta & Sig.* & Coefficients for & RSquare & Beta & Sig.* \\
\hline Overall Rating & 0.044 & -0.939 & 0.018 & Overall Rating & 0.151 & 0.767 & 0.179 \\
\hline Community Rating & 0.010 & -0.466 & 0.270 & Community Rating & 0.045 & 0.570 & 0.372 \\
\hline Employee Ratings & 0.076 & -1.771 & 0.002 & Employee Ratings & 0.334 & 2.020 & 0.006 \\
\hline Governance Ratings & 0.053 & -1.305 & 0.009 & Governance Ratings & 0.107 & 0.240 & 0.745 \\
\hline Environment Ratings & 0.005 & -0.344 & 0.418 & Environment Ratings & 0.009 & 0.017 & 0.979 \\
\hline${ }^{*} p<0.05$ & & & & ${ }^{*} p<0.05$ & ${ }^{* *}$ Controlle & be of $\mathrm{CO}$ & $($ F.B. \\
\hline
\end{tabular}

Table 10 shows the results for controlled model. After controlling for company type, number of family members in TMT resulted positive in the employee CSR ratings and not significant for all other ratings. Therefore, we can conclude that family businesses with more family member in TMT have lower CSR performance than businesses with less family member in TM, but family businesses with more family members in TMT have higher CSR performance than family businesses with less family members in TMT. Hence Hypothesis 2 is partially supported.

\begin{tabular}{lccc}
\hline \multicolumn{1}{c}{ TABLE 5 } & \multicolumn{3}{c}{ Predictor Variable: Family CEO } \\
\hline Coefficients for & R Square & Unstandardized \\
\hline Overall Rating & 0.05 & -4.19 & Sig. $^{*}$ \\
Community Rating & 0.01 & -2.31 & 0.01 \\
Employee Ratings & 0.13 & -9.33 & 0.18 \\
Governance Ratings & 0.00 & -1.20 & 0.00 \\
Environment Ratings & 0.04 & -4.32 & 0.03 \\
\hline * p O.05 & & &
\end{tabular}

Hypothesis 3 stating that presence of family CEO diminishes the CSR performance is tested with regression analysis and results in Table 5 shows that Family CEO has significant negative impact in 3 out of 5 CSR categories. 


\begin{tabular}{lccc}
\hline \multicolumn{1}{c}{ TABLE 5} & \multicolumn{3}{c}{ Predictor Variable: Family CEO } \\
\hline & \multicolumn{3}{c}{ Unstandardized } \\
Coefficients for & R Square & Beta & Sig. $^{*}$ \\
\hline Overall Rating & 0.05 & -4.19 & 0.01 \\
Community Rating & 0.01 & -2.31 & 0.18 \\
Employee Ratings & 0.13 & -9.33 & 0.00 \\
Governance Ratings & 0.00 & -1.20 & 0.48 \\
Environment Ratings & 0.04 & -4.32 & 0.03 \\
\hline
\end{tabular}

\begin{tabular}{|c|c|c|c|}
\hline \multirow[t]{2}{*}{ TABLE 6} & \multicolumn{3}{|c|}{ Predictor Variable: Family CEO** } \\
\hline & \multicolumn{3}{|c|}{ Unstandardized } \\
\hline Coefficients for & R Square & Beta & Sig.* \\
\hline Overall Rating & 0.140 & -0.861 & 0.628 \\
\hline Community Rating & 0.039 & -0.433 & 0.828 \\
\hline Employee Ratings & 0.299 & -2.651 & 0.249 \\
\hline Governance Ratings & 0.010 & -0.298 & 0.883 \\
\hline Environment Ratings & 0.107 & -0.480 & 0.834 \\
\hline
\end{tabular}

Analyzing the effect of family CEO among all companies resulted in negative significant values, but after controlling for company type, results in Table 6 shows that Family CEO does not have any significant impact. Therefore, we can conclude that family businesses with family CEO have lower CSR performance than businesses with nonfamily CEO, but family businesses with family CEO are not any different than family businesses with nonfamily CEO. Hence Hypothesis 3 is partially supported.

\begin{tabular}{lccc} 
TABLE 7 & \multicolumn{3}{c}{ Predictor Variable: Family Chairman } \\
\hline Coefficients for & R Square & Unstandardized \\
\hline Overall Rating & 0.13 & -5.64 & Sig. $^{*}$ \\
Community Rating & 0.06 & -4.04 & 0.00 \\
Employee Ratings & 0.19 & -9.58 & 0.00 \\
Governance Ratings & 0.04 & -3.46 & 0.02 \\
Environment Ratings & 0.08 & -5.50 & 0.00 \\
\hline${ }^{*} p<0.05$ & & &
\end{tabular}

Hypothesis 4 is tested using regression analysis and results are shown in Table 7. Hypothesis 4 is stating that presence of Family Chairman diminishes the CSR performance of family businesses in all categories. Table 7 results support Hypothesis 4 . All of the $p$ values are significant and all beta values are negative. 


\begin{tabular}{lccc}
\hline & \multicolumn{3}{c}{ Unstandardized } \\
Coefficients for & RSquare & Beta & Sig. $^{*}$ \\
\hline Overall Rating & 0.13 & -5.64 & 0.00 \\
Community Rating & 0.06 & -4.04 & 0.00 \\
Employee Ratings & 0.19 & -9.58 & 0.00 \\
Governance Ratings & 0.04 & -3.46 & 0.02 \\
Environment Ratings & 0.08 & -5.50 & 0.00 \\
\hline${ }^{*} p<0.05$ & & &
\end{tabular}

\begin{tabular}{lccc}
\hline & \multicolumn{3}{c}{ Unstandardized } \\
Coefficients for & R Square & Beta & Sig. $^{*}$ \\
\hline Overall Rating & 0.153 & -2.938 & 0.148 \\
Community Rating & 0.061 & -3.854 & $0.088^{* *}$ \\
Employee Ratings & 0.292 & -0.750 & 0.777 \\
Governance Ratings & 0.055 & -5.563 & 0.015 \\
Environment Ratings & 0.108 & -1.354 & 0.607 \\
\hline${ }^{*} p<0.05{ }^{* *} p<0.1$ & ${ }^{* * *}$ Controlled for Type of Company (F.B.)
\end{tabular}

Results of Table 7 compared with the results of control model at Table 8. Effect of family chairman compared to all other companies with nonfamily Chairman resulted in favor of nonfamily businesses. Furthermore, when companies with family chairman compared to family businesses with nonfamily chairman resulted in negative outcomes in 2 out of 5 categories. Therefore, we can conclude that family businesses with family chairman have lower CSR performance than businesses with nonfamily Chairman, but family businesses with family Chairman are not much different than family businesses with nonfamily Chairman. Hence Hypothesis 4 is supported.

\section{DISCUSSION}

Investigating the difference between family and nonfamily business is the key concept of the family business literature. In this study, we showed that family businesses are significantly different than nonfamily businesses in many aspects of the corporate social responsibility. Studies about TMT characteristics of family business are one of the rare kinds in family business literature (Minichilli et al., 2010; Kellermanns \& Eddleston, 2004, 2007; Ling \& Kellermanns, 2010). Analyzing CSR performance in relation to TMT composition in family businesses was a missing part of this rare literature. This study provides insights about how family business specific TMT composition affects the CSR performance of family businesses.

Hypothesis 1 tested main difference between family and nonfamily businesses in terms of CSR performance. Results show that nonfamily businesses do better in overall, community, employee, and environment CSR performance ratings. In governance ratings, family businesses are not any different than nonfamily businesses. But considering the negative $B$ value, we assume that it is possible that family businesses are not better than nonfamily businesses. These results support the agency perspective suggesting that there could be limitations of familiness 
towards the other stakeholder's expectations. Therefore, seeing that community ratings decrease 3.13 point, employee ratings decrease 11.59 and environment ratings decrease 6.20 with family businesses presence, is a support that family businesses might have weakness when it comes to nonfamily stakeholders. Even after controlling for company size and age, the results are not significantly changed, and still nonfamily businesses have better CSR performance than family businesses.

Hypothesis 3 claiming that family CEO diminishes the family business CSR performance is supported by the results. Family businesses with family CEO have lower CSR ratings than all businesses without family CEO. When this is investigated only among the family businesses, it is still that family businesses with family CEO have lower CSR performance than family businesses with nonfamily CEO. Family CEO creates significantly negative result in overall $(p<0.05, B-4.19)$, employee $(p<0.05, B-9.33)$ and environment $(p<0.05, B-4.32)$. Results are supporting the literature suggesting that family control might influence the objective decisions of the family CEO and in return decisions might be in favor of noneconomic goals of controlling family. This might result having nonfamily stakeholders like environment and employee to be kept outside the decision making process.

Hypothesis 3 claiming that presence of family chairman will diminish the CSR performance of family businesses is supported by the results. Unlike the family CEO, when family chairman is in charge, all categories of the CSR performance is negatively affected. When this analysis is done by controlling company type, still family chairman resulted in negative outcome for community and governance ratings. Therefore, literature suggesting that family chairman is the knight of the family to make sure that company is run by the rules and desires of the family not by the whole stakeholder's benefit.

Hypothesis 4 investigated the effects of number of family members in TMTs. Results show that increased family presence has negative impact on the overall $(p<0.05, B-0.94)$, governance $(p<0.05, B-1.30)$ and employee $(p<0.05, B-1.77)$ ratings. Top management diversity studies have argued some benefits and drawbacks of composition on TMT performance (Hambrick et al., 1996; Hambrick \& Mason, 1984; Carpenter et al., 2004). These findings also implicitly refer to performance of CSR due to correlation between performance and CSR (Orlitzky et al., 2003; McWilliams and Siegel, 2000). Furthermore, when we investigate the phenomena among only family businesses, our findings suggest that when there are a higher number of family members in TMT, CSR performance is better in employee relationships. Although studies argue that family business employees are not satisfied and well 
taken care of (Beehr et al., 1997; Block et al., 2013), number of family members in TMT might be an unexplained variable in the equation.

Therefore, we conclude that family businesses are well governed (not significant governance ratings) but ignored the employee, environment and community issues. Although Dyer and Whetten (2006) argue that family businesses are socially responsible due to family name involvement, it is partially with this study while results are mostly supporting contrary opinion (Morck \& Yeung, 2004) that family businesses are not socially responsible and not caring for neither community nor environment. Additional analysis of family CEO, family chairman, age of the company and industry of the company revealed important findings for literature. While family CEO has negative impact on only 3 categories, family chairman has negative impact on all categories. These results are also supported in the literature. Deniz and Suarez (2005) argue that family businesses without family CEOs are better in CSR performance. Analysis of age of the company revealed that age is significant contributor to CSR performance of all companies including the family business while size does not have any significant effect on CSR performance.

\section{LIMITATIONS AND FUTURE RESEARCH}

Findings of this study should be taken with considering the limitations, which most of the research poses. The main limitations of this research is sampling. First, sample is taken from top 100 family businesses in United States and top 500 nonfamily businesses. This brings some limitations like being restricted to a certain geographic area and considering only top performers. Furthermore, top family businesses might not be completely comparable with the top nonfamily businesses. Moreover, selection of companies was limited to companies which have publicly available data. Therefore, future research should extend the sample selection and include more privately held small and medium size companies (Ciocirlan, 2008) and pull the sample from the same categorization to increase the generalizability.

Another limitation of study is secondary data. Family business field researchers admit that it is difficult to collect primary data on family business issues due to not being either publicly owned or study involving mostly the executive team. Hence, our study is not derived on primary data which might reveal more insightful and exploratory findings. Therefore, we suggest that future research should run similar study with primary data. 
Finally, the methodology of sample collection is another limitation to be mentioned. Cross sectional data collection is one of the ways to achieve a statistical data but longitudinal data collection provides more in-depth information about the phenomena. For instance, comparing the family CEO period with nonfamily CEO period would provide more in-depth data than cross-sectional data. 


\section{REFERENCES}

Allen, T., \& Cohen, S. (1969). Information flow in research and development laboratories. Administrative Science Quarterly, 14: 12-19.

Anderson, R. C., \& Reeb, D. M. (2003). Founding-family ownership and family performance: Evidence from the S\&P 500. The Journal of Finance, 58(3), 1302-1328.

Andres, C. (2008). Large shareholders and firm performance-An empirical examination of founding-family ownership. Journal of Corporate Finance, 14(4), 431-445.

Barontini, R., \& Caprio, L. (2006). The effect of family control on firm value and performance: Evidence from continental Europe. European Financial Management, 12(5), 689-723.

Beehr, T. A., Drexler Jr, J. A., \& Faulkner, S. (1997). Working in small family businesses: Empirical comparisons to non-family businesses. Journal of Organizational Behavior, 297-312.

Besser, T. L. (1999), “Community involvement and perceptions of success among small business operators in small towns", Journal of Small Business Management, 37 (4), 16-29

Besser, T. L., \& Miller, N. (2001). Is the good corporation dead? The community social responsibility of small business operators. Journal of Socio-Economics, 30(3), 221-241.

Block, J. H., \& Wagner, M. (2010). Corporate social responsibility in large family and founder firms (No. ERS2010-027-ORG). ERIM Report Series Research in Management.

Block, J. H., Millán, J. M., Román, C., \& Zhou, H. (2015). Job satisfaction and wages of family employees. Entrepreneurship Theory and Practice, 39(2), 183-207.

Bouvain, P., Baumann, C., \& Lundmark, E. (2013). Corporate social responsibility in financial services: A comparison of Chinese and East Asian banks vis-à-vis American banks. International Journal of Bank Marketing, 31(6), 420-439.

Boyd, B. K., Gove, S., \& Hitt, M. A. (2005). Construct measurement in strategic management research: Illusion or reality? Strategic Management Journal, 26(3), 239-257.

Breton, I. L., \& Miller, D. (2006). Why do some family businesses out-compete? Governance, long-term orientations, and sustainable capability. Entrepreneurship Theory and Practice, 30(6), 731-746

Byrne, D., \& Wong, T. J. (1962). Racial prejudice, interpersonal attraction, and assumed dissimilarity of attitudes. The Journal of Abnormal and Social Psychology, 65(4), 246.

Cannella, A. A., \& Holcomb, T. R. (2005). A multi-level analysis of the upper-echelons model. In Multi-level issues in strategy and methods (pp. 195-237). Emerald Group Publishing Limited.

Carpenter, M. A., \& Fredrickson, J. W. (2001). Top management teams, global strategic posture, and the moderating role of uncertainty. Academy of Management Journal, 44(3), 533-545.

Carpenter, M. A., Geletkanycz, M. A., \& Sanders, W. G. (2004). Upper echelons research revisited: Antecedents, elements, and consequences of top management team composition. Journal of Management, 30(6), 749778 .

Caselli, F., \& Gennaioli, N. (2013). Dynastic management. Economic Inquiry, 51(1), 971-996.

Chrisman, J. J., Chua, J. H., \& Litz, R. A. (2004). Comparing the Agency Costs of Family and Non-Family Firms: Conceptual Issues and Exploratory Evidence. Entrepreneurship Theory and Practice, 28(4), 335-354.

Chrisman, J. J., Chua, J. H., \& Steier, L. (2005). Sources and consequences of distinctive familiness: An introduction. Entrepreneurship Theory and Practice, 29(3), 237-247. 
Chrisman, J. J., Chua, J. H., \& Steier, L. P. (2011). Resilience of family firms: An introduction. Entrepreneurship theory and practice, 35(6), 1107-1119.

Chrisman, J. J., Chua, J. H., \& Zahra, S. A. (2003). Creating wealth in family firms through managing resources: Comments and extensions. Entrepreneurship Theory and Practice, 27(4), 359-365.

Chrisman, J. J., Chua, J. H., Pearson, A. W., \& Barnett, T. (2012). Family Involvement, Family Influence, and Family-centered Non-Economic Goals in Small Firms. Entrepreneurship theory and practice, 36(2), 267293.

Chrisman, J.J., Chua, J.H., Kellermanns, F., \& Chang, E. (2007). Are family managers agents or stewards? An exploratory study in privately held family firms. Journal of Business Research, 60(10), 1030-1038.

Chu, W. (2011). Family ownership and firm performance: Influence of family management, family control, and firm size. Asia Pacific Journal of Management, 28(4), 833-851.

Chua, J. H., Chrisman, J. J., \& Sharma, P. (1999). Defining the family business by behavior. Entrepreneurship theory and practice, 23(4), 19-39.

Ciocirlan, C. (2008). Analyzing the social responsibility of small, family-owned Business: A Research Agenda. Journal of applied management and Entrepreneurship, 13(4), 86-100.

Corbetta, G. \& Salvato, C. (2004). Self-serving or self-actualizing? Models of man and agency costs in different types of family firms: A commentary on comparing the agency costs of family and non-family firms: Conceptual issues and exploratory evidence. Entrepreneurship Theory and Practice, 28(4), 355-362.

Davis, P. S., \& Harveston, P. D. (1999). In the founder's shadow: Conflict in the family firm. Family Business Review, 12(4), 311-323.

Deloitte \& Touche Study (1999). Are Canadian family businesses an endangered species? The first success readiness survey of Canadian family-owned business. University of Waterloo, ON: Deloitte \& Touche Centre for Tax Education and Research.

Demsetz, H., \& Lehn, K. (1985). The structure of corporate ownership: Causes and consequences. The Journal of Political Economy, 93(6), 1155-1177.

Déniz, M. D. L. C. D., \& Suárez, M. K. C. (2005). Corporate social responsibility and family business in Spain. Journal of Business Ethics, 56(1), 27-41.

Drucker, P. (1974). Management: Tasks, responsibilities, practices. New York: Harper \& Row.

Dyer, W. G., \& Whetten, D. A. (2006). Family firms and social responsibility: Preliminary evidence from the S\&P 500. Entrepreneurship Theory and Practice, 30(6), 785-802.

Ensley, M. D., \& Pearson, A. W. (2005). An exploratory comparison of the behavioral dynamics of top management teams in family and nonfamily new ventures: Cohesion, conflict, potency, and consensus. Entrepreneurship Theory and Practice, 29(3), 267-284.

Ensley, M. D., Pearson, A. W., \& Sardeshmukh, S. R. (2007). The negative consequences of pay dispersion in family and non-family top management teams: An exploratory analysis of new venture, high-growth firms. Journal of Business Research, 60(10), 1039-1047.

Ewing, D.W. (1965). Is nepotism so bad? Harvard Business Review, 43(1), 22.

Finkelstein, S., \& Hambrick, D. C. (1990). Top-management-team tenure and organizational outcomes: The moderating role of managerial discretion. Administrative Science Quarterly, 484-503.

Finkelstein, S., \& Hambrick, D. C. (1996). Strategic leadership: Top executives and their effects on organizations. Minneapolis: West Publishing. 
Gersick, K. E., Davis, J. A., Hampton, M. M. and Lansberg, I. (1997). Generation to Generation: Life Cycles of the Family Business. Boston, MA: Harvard Business School Press.

Godfrey, P.C. (2005). The relationship between corporate philanthropy and shareholder wealth: A risk management perspective. Academy of Management Review, 30(4), 777-798.

Godos-Díez, J. L., Fernández-Gago, R., \& Martínez-Campillo, A. (2011). How important are CEOs to CSR practices? An analysis of the mediating effect of the perceived role of ethics and social responsibility. Journal of Business Ethics, 98(4), 531-548.

Gomez-Mejia, L. R., Nunez-Nickel, M., \& Gutierrez, I. (2001). The role of family ties in agency contracts. Academy of management Journal, 44(1), 81-95.

Gupta, A. K. (1988). Contingency perspectives on strategic leadership: Current knowledge and future research direction. In D. C. Hambrick (Ed.), The executive effect: Concepts and methods for studying top managers: 147-178. Greenwich, CT: JAI Press.

Habbershon, T. G., \& Williams, M. L. (1999). A resource-based framework for assessing the strategic advantages of family firms. Family Business Review, 12(1), 1-25.

Habbershon, T. G., Williams, M., \& MacMillan, I. C. (2003). A unified systems perspective of family firm performance. Journal of business venturing, 18(4), 451-465.

Haleblian, J., \& Finkelstein, S. (1993). Top management team size, CEO dominance, and firm performance: The moderating roles of environmental turbulence and discretion. Academy of Management Journal, 36(4), 844-863.

Hambrick, D. C., \& Mason, P. A. (1984). Upper echelons: The organization as a reflection of its top managers. Academy of management review, 9(2), 193-206.

Hambrick, D. C., Cho, T. S., \& Chen, M. J. (1996). The influence of top management team heterogeneity on firms' competitive moves. Administrative science quarterly, 659-684.

Hiebl, M. R. (2012). Risk aversion in family firms: what do we really know?. The Journal of Risk Finance, 14(1), 49-70.

Jenkins, H. (2006). Small business champions for corporate social responsibility. Journal of Business Ethics, 67(3), 241-256.

Jensen, M. C., \& Meckling, W. H. (1976). Theory of the firm: Managerial behavior, agency costs and ownership structure. Journal of financial economics, 3(4), 305-360.

Kachaner, N., Stalk, G., \& Bloch, A. (2012). What you can learn from family Business. Harvard Business Review, 90(11), 102-106.

Karra, N., Tracey, P., \& Phillips, N. (2006). Altruism and agency in the family firm: Exploring the role of family, kinship, and ethnicity. Entrepreneurship Theory and Practice, 30(6), 861-877.

Katz, R. (1982). The effects of group longevity on project communication and performance. Administrative Science Quarterly, 27: 81-104.

Kellermanns, F. W., \& Eddleston, K. A. (2004). Feuding families: When conflict does a family firm good. Entrepreneurship Theory and Practice, 28(3), 209-228.

Kellermanns, F. W., \& Eddleston, K. A. (2007). A family perspective on when conflict benefits family firm performance. Journal of Business Research, 60(10), 1048-1057.

Kotler, P. \& Lee, N. (2005). Corporate Social Responsibility: doing the most good for your company and your cause Wiley Publications, New Jersey, USA 
Lee, M. S., \& Rogoff, E. G. (1996). Research note: Comparison of small businesses with family participation versus small businesses without family participation: An investigation of differences in goals, attitudes, and family/business conflict. Family Business Review, 9(4), 423-437.

Ling, Y., \& Kellermanns, F. W. (2010). The effects of family firm specific sources of TMT diversity: The moderating role of information exchange frequency. Journal of Management Studies, 47(2), 322-344.

Litz, R. A. (1995). The family business: Toward definitional clarity. Family Business Review, 8(2), 71-81.

Manner, M. H. (2010). The impact of CEO characteristics on corporate social performance. Journal of business ethics, 93(1), 53-72.

McGuire, J., Dow, S., \& Argheyd, K. (2003). CEO incentives and corporate social performance. Journal of Business Ethics, 45(4), 341-359.

McWilliams, A., \& Siegel, D. (2000). Corporate social responsibility and financial performance: correlation or misspecification? Strategic management journal, 21(5), 603-609.

Miller, D. \& Le-Breton-Miller, I. (2005). Managing for the long run: Lessons in competitive advantage from great family businesses. Boston: Harvard Business School Press.

Miller, D., Le Breton-Miller, I., Lester, R. H., \& Cannella Jr, A. A. (2007). Are family firms really superior performers?. Journal of corporate finance, 13(5), 829-858.

Minichilli, A., Corbetta, G., \& MacMillan, I. C. (2010). Top Management Teams in Family-Controlled Companies: 'Familiness', 'Faultlines', and Their Impact on Financial Performance. Journal of Management Studies, 47(2), 205-222.

Morck, R. \& Yeung, B. (2004). Family control and the rent-seeking society. Entrepreneurship Theory and Practice, 28(4), 391-409

Morck, R. \& Yeung, B. (2003). Agency problems in large family business groups. Entrepreneurship Theory \& Practice, 27(4), 367-382.

Murray, A. I. (1989). Top management group heterogeneity and firm performance. Strategic Management Journal, $10(1), 125-141$.

Niehm, S.L., Swinney, J. \& Miller N.J. (2008). Community Social Responsibility and its consequences for family business performance. Journal of Small Business Management, 46(3), 331-350

Nordqvist, M. (2005). Familiness in top management teams: Commentary on Ensley and Pearson's "an exploratory comparison of the behavioral dynamics of top management teams in family and nonfamily new ventures: Cohesion, conflict, potency, and consensus". Entrepreneurship Theory and Practice, 29(3), 285-292.

O'Boyle, E.H., Rutherford, M.W., and Pollack J.M. (2010), Examining the relation between ethical focus and financial performance in family firms: An exploratory study, Family Business Review, 23(4), 310-326

O'Reilly, C. A., III, Caldwell, C., \& Barnett, D. (1989). Work group demography, social integration, and turnover. Administrative Science Quarterly, 34: 21-37.

Orlitzky, M., Schmidt, F. L., \& Rynes, S. L. (2003). Corporate social and financial performance: A meta-analysis. Organization studies, 24(3), 403-441.

Pearson, A. W., \& Lumpkin, G. T. (2011). Measurement in Family Business Research: How Do We Measure Up?. Family Business Review, 24(4), 287.

Priem, R.L. (1990). Top management team group factors, consensus and firm performance. Strategic Management Journal, 11(6), 469-478. 
Quazi, A. M., \& O'Brien, D. (2000). An empirical test of a cross-national model of corporate social responsibility. Journal of Business Ethics, 25(1), 33-51.

Ramasamy, B., N. H. Ling and H. W. Ting: 2007, 'Corporate Social Performances and Ethnicity. A Comparison between Malay and Chinese Chief Executives in Malaysia’, International Journal of Cross Cultural Management 7(1), 29-45.

Rhodes, S. R. (1983). Age-related differences in work attitudes and behavior: A review and conceptual analysis. Psychological bulletin, 93(2), 328.

Ryder, N. B. (1985). The cohort as a concept in the study of social change. In Cohort analysis in social research (pp. 9-44). Springer, New York, NY.

Schulze, W. S., Lubatkin, M. H., Dino, R. N., \& Buchholtz, A. K. (2001). Agency relationships in family firms: Theory and evidence. Organization science, 12(2), 99-116.

Sharma, P., Chrisman, J. J., \& Chua, J. H. (1997). Strategic management of the family business: Past research and future challenges. Family business review, 10(1), 1-35.

Simons, T., Pelled, L. H., \& Smith, K. A. (1999). Making use of difference: Diversity, debate, and decision comprehensiveness in top management teams. Academy of management journal, 42(6), 662-673.

Singhapakdi, A., Gopinath, M., Marta, J. K., \& Carter, L. L. (2008). Antecedents and consequences of perceived importance of ethics in marketing situations: a study of Thai businesspeople. Journal of Business Ethics, 81(4), 887-904.

Smith, K. G., Smith, K. A., Olian, J. D., Sims, H. P., O’Brannon, D. P. and Scully, J. A. (1994). Top management team demography and process: the role of social integration and communication. Administrative Science Quarterly, 39, 412-38.

Sonfield, M. C., \& Lussier, R. N. (2009). Family-member and non-family-member managers in family businesses. Journal of Small Business and Enterprise Development, 16(2), 196-209.

Thaler, R. \& Shefrin, H. (1981). An economic theory of self-control. Journal of Political Economy, 89(2), 392406.

Thanetsunthorn, N., \& Wuthisatian, R. (2016). Current state of corporate governance: Global business and cultural analysis. Management Research Review, 39(11), 1431-1446.

Thomas, J. (2009). Attitudes and expectations of shareholders: The case of the multi-generation family business. Journal of Management and Organization, 15(3), 346-362

Uhlaner, L. M., van Goor-Balk, H. A., \& Masurel, E. (2004). Family business and corporate social responsibility in a sample of Dutch firms. Journal of Small Business and Enterprise Development, 11(2), 186-194.

Wagner, W. G., Pfeffer, J., \& O'Reilly, C. A., III. (1984). Organizational demography and turnover in topmanagement groups. Administrative Science Quarterly 29: 74-92.

Waldman, D. A., \& Siegel, D. (2008). Defining the socially responsible leader. The Leadership Quarterly, 19(1), 117-131.

Wiersema, M. F., \& Bantel, K. A. (1992). Top management team demography and corporate strategic change. Academy of Management journal, 35(1), 91-121.

Zahra, S. A., J. C. Hayton, et al. (2004). "Entrepreneurship in Family vs. Non-Family Firms: A Resource-Based Analysis of the Effect of Organizational Culture." Entrepreneurship: Theory \& Practice 28(4): 363-381.

Zenger, T. R., \& Lawrence, B. S. (1989). Organizational demography: The differential effects of age and tenure distributions on technical communication. Academy of Management Journal, 32(2), 353-376. 